Conspectus

Rhetorics of Response to 9/11

\title{
The Aftermath of Terror
}

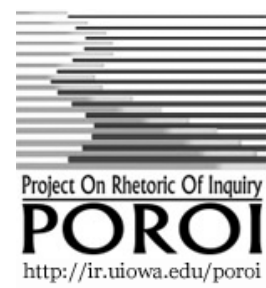

\author{
John S. Nelson
}

Poroi, 2, 1, August, 2003

The strategy of terror is a spectacularly failed one. ${ }^{1}$ - Caleb Carr

1 Terror, like panic, might be almost impossible to sustain. It strikes and spikes with virtual simultaneity; it decays nearly as fast. It consumes personal and historical moments that might last beyond minutes and hours to days and weeks, but it rages too hot and ranges too far to leave fuel for durable burns. This, unfortunately, is the good news. The bad news is that terror all too readily recurs; and when it doesn't, it echoes - in some settings, seemingly without end.

2 As a strategy, terrorism targets bystanders, civilians, "innocents" in a still decent sense of the word. That is why Caleb Carr, the military historian and popular novelist of note, argues that sustained terrorism does not succeed. ${ }^{2}$ Outrageous violence against noncombatants spurs people to resist terrorists categorically. It mobilizes whole populations to extraordinary resolution, even desperation, so that they do whatever it takes over the long haul to destroy terrorist forces while discrediting terrorist causes. Not once in history, claims Carr, has a terrorist campaign in war or insurgency succeeded for long. Individuals and governments must not overreact and respond in kind to terrorism. The main hope of terrorists is to provoke self-defeating terrorism in return. ${ }^{3}$

3 Government terrorism might be another matter. In people, terror spirals into psychosis and breakdown or atrophies into anxiety. In politics, terror sometimes takes the iron enclosure, utter domination, and systematic inefficiency of the totalitarian regime as a method for turning the perversity inward, leaving terror to feed indefinitely on itself. Yet experience suggests that actual totalitarianism falls after a few years or decades into a malaise of immorality too placid and pragmatic to count as terror, even 
though it is stoked by terrorist devices like concentration camps, death squads, and secret police. These are endurable, more or less, because they rarely reach for most people the fever pitch of fullfledged terror. At least in a world providing external political alternatives, we have learned, regimes of terror gradually routinize themselves into more traditional patterns of oppression and exploitation. Eventually a pervasive corruption can erode further the rigor of any terror, opening such regimes to reform, liberalization, or dissolution from within - and invasion from without. ${ }^{4}$ Most terror stays local in space and momentary in time.

4 This happens in part because terror depends on unpredictability so radical that it undoes itself, preventing even a pattern of surprise. In consequence, campaigns of terror require rapid, irregular acts of increasingly devilish invention. Even then terrorist attacks settle more readily into unconventional warfare by such horrendous means as martyr bombers and street assassins. Dread can ensue instead, but it differs considerably from terror. Conducted in dread, everyday life expects catastrophe but plods timidly or doggedly ahead. ${ }^{5}$

5 Terror shocks so deeply and stuns so decisively that we feel recovery is impossible, only to find ourselves unable later to tie its awful trauma to ordinary affairs. Terror disrupts routines apparently beyond repair, but dissipates rapidly into daytime amnesia. ${ }^{6}$ The strange injunction to "return to normalcy" so as "not to let the terrorists win" testifies to the discombobulation induced by terror. In the aftermath of terror, such exhortations go overnight from absurd and undoable to simply unnecessary. The resulting routines might differ in detail from before, and the echoes of terror might unsettle us for decades in some places or practices, yet the terror itself can dissipate rapidly in sensation and consequence. Air travel "will never be the same" after 9/11, to be sure, but even now does it differ significantly from before? For all the economical and psychological upheaval inflicted on the airline industry, have the accomplices of Usama bin Laden somehow transformed even that part of American culture, capitalist transportation, or western civilization? Not by much, if at all save by rhetoric.

6 Like other politics, terrorism is theatrical, performative, therefore rhetorical. 7 But terror can be so evanescent by comparison with other political experiences that terrorism must rely for political effects primarily on the rhetorics in its aftermath. Rhetorics in response to terrorists acts can construct enduring meanings and 
effects for them, inflecting their details in relatively lasting directions. The first terrorist bombing of the World Trade Center, in 1993, attracted momentary attention in America but generated scant rhetoric in response and next to no public memory. The embassy bombings soon to follow in other countries did not create in this one the echoing waves of terror sought by al Qaeda. Rhetorics of response seldom connected these dots with any sense of clarity or urgency in a specific direction. The Washington Snipers kept the nation's capital in turmoil on the edge of terror for days, and the Anthrax Assassin for weeks, because our rhetorics helped their deeds echo al Qaeda's even after the conventional wisdom became that neither set of attacks tied organizationally or motivationally to Islamic fundamentalism turned anti-American.

7 In the aftermath of terror, our rhetorics produce the dots or don't and connect them or not. Far more than the words in our moments of terror, let alone the raw violations or feelings in such overwhelming experiences, our rhetorics in response define the perspectives and resolutions that emerge. The injuries of victims, the grievances of terrorists, the obligations of governments, the strategies of media, the responsibilities of citizens: all take firm shape only after terror subsides and responses ensue.

8 Rhetorics of response to 9/ 11 are the topic for this special issue of Poroi. Insistently the contributions connect politics and art, economics and media, philosophy and personal reflection, government and popular culture. Thomas Shevory tackles the interplay of commerce, music, and humor in the rhetorics that range "From Censorship to Irony." Aimee Carrillo Rowe and Sheena Malhotra analyze official talk and everyday media to disclose a "Chameleon Conservatism" that protests America's political innocence and protects its hegemonic interests in the wake of 9/11. In "Ground Zero, an American Origin," Mary Caputi draws on Walter Benjamin's idea of originary ruins to recognize in the rubble of the World Trade Center an allegory of consumer society in collapse. As an electronic journal, Poroi does not face the page limits imposed by print, and it welcomes diverse articles of scholarship distinguished by insight and style. These three pieces also illustrate the interdisciplinary scope of Poroi's abiding passion for rhetorical analysis and invention.

9 The journal encourages unconventional contributions to scholarship as well. They arise from what its sponsoring Project on Rhetoric of Inquiry calls new practices of inquiry. POROI, in 
acronymic caps, has invented rhetoric of inquiry, helped to pioneer multimedia scholarship, promoted cultural studies and political aesthetics, and supported various other initiatives that tie strongly to rhetorical analysis and invention. These inspire or result from new forms and devices of scholarship. Now Poroi seeks to spotlight these experiments in genre and method by publishing occasional features that deserve to inspire successors. This issue introduces several:

10 The Conspectus takes exigencies for the present issue of the journal as a platform for rhetorical performance. It introduces the focal contributions by engaging their mutual implications, individual innovations, and other implications for intellectual community among the writers and readers of Poroi.

11 Film Takes are exercises for appreciating the rhetorics of individual films or cinematic genres. They try to be timely guides to viewing, as befits a world with DVDs and VCRs, but their scholarly ambition exceeds movie reviews that assign stars to say what films to see and what to skip.

12 Multimedia Inquiries are experiments with scholarship in media beyond print. To create multimedia scholarship, they take advantage of the capacities of online publication to address rhetorics with images and sounds as well as words.

13 Myth Scapes are essays in the rhetorical analysis of familiar objects from popular cultures. They treat objects as constellations of myths. Like their prototypes, the "mythologies" by Roland Barthes, these essays tend to be snappy and playful.

14 Rhetorical Inventions are explorations of notable topics in forms more inventive, and often in terms more personal, than have become conventional for scholarship. This is a genre of generic innovation, open to innumerable modes and moves of potential interest to scholars.

15 Strategy Studies are examinations of the ends and means, strategies and tactics, plus advantages and dangers in specific rhetorics. They are where the disciplined work of rhetorical analysis proceeds in relatively traditional terms, if sometimes in more personal terms and modern forms.

16 Word Tours are excursions into the revealing meanings and connections among telling concepts. They tap the tropal powers of 
rhetorical analysis and invention to post questions, refine observations, advance arguments, improve theories, and entertain readers.

17 Poroi has no ambition to publish every kind of feature in every issue. Together the present issue and the next ones provide a full complement of the current kinds because prospective contributors need examples to guide and provoke them. Evocations and instructions for each kind appear in the journal's architecture, as I call it: the parts of the Web site for Poroi that go beyond specific issues of the journal. This supporting structure of information also evokes Poroi's purposes, authors, editors, and processes for submission and subscription. (Authors retain copyrights, while subscribers access issues new and old for free, so Poroi plays hard to resist.) We encourage scholars to approach any of the Poroi editors about further possibilities for features, special issues, or specific contributions.

18 To probe rhetorics of response to the terrorist attacks on September 11, 2001, Dana Cloud calls on personal experience and conceptual invention to parse rhetorical strategies of "Therapy, Silence, and War." In a literary mode of rhetorical invention, Christopher Merrill, the Director of Iowa's International Writing Program, chronicles echoes of 9/11 as "The Sound of Falling." I reflect on "Four Forms for Terrorism" in popular cinema. Francis Beer and G. R. Boynton contribute a multimedia inquiry on conventions used by television in "Globalizing Terror." Russell Valentino's word tour is the one feature not defined by the issue's overarching theme, yet his stroll "From the Challenge of Virtue to the Challenges of Virtual" is bound to fascinate many among us.

19 This initial issue of the second volume relaunches Poroi after a hiatus for redesign. The inaugural issue, focused on "Rhetorics of Biology in the Age of Biomechanical Reproduction," is being republished in the updated format. If you have yet to read it, another feast awaits you. The new format has been financed by Iowa Graduate Dean J ohn C. Keller and POROI Executive Director David Depew. Their support enabled J. R. Boynton to conceive the look and construct the navigation that now brings you Poroi articles and features. Thanks go to them all, and to the University of Iowa Libraries for continuing to publish and archive the journal. Special thanks go to the associate editors, the managing editor, and members of the editorial board for lots and lots of incisive advice about the journal's administration, architecture, 
and submissions.

20 In the aftermath of terror, our rhetorics tell the tale, pipe the tune, make the memories, shape the politics. What rhetorics might lack in momentary bang, they can make up in political reverberation. Most terrorism is too volatile in detail and precarious in duration to define even its own meanings long term. The one regime of terror that has engulfed the globe for decades is not so much political as military and apocalyptic. It is the shadow of the doomsday weapon, one not merely of "mass destruction" but total annihilation.

21 In the wake of the Cold War, that terror takes a different form than in the second half of the twentieth century. No more do we face the MADness of a superpower showdown between the USA and the USSR. The new specter is a sabotage of civilization by suitcase bombs that provoke longer-range missiles from a profusion of regional conflicts that escalate beyond all restraint. The terror of nuclear annihilation endures, now augmented by doomsday germs and poisons.

22 Perhaps this is why we have found it so hard to invent effective rhetorics for facing the terrors of a humanly imposed apocalypse. So far those are the stuff of nightmares rather than rhetorics. They stay repressed in everyday politics and foreign policies, but express themselves in profound disturbances of popular music, image, and language. ${ }^{8}$ In invention is analysis, and in analysis invention. As we analyze rhetorics of response to $9 / 11$, might we begin as well to invent rhetorics for taming the total terrorism of our times: the terror to end all terror - and everything else? At least to me, the particulars in the present issue imply no optimism on this further question. Might a few of the forms hold out nonetheless a modicum of hope?

(C) John S. Nelson, 2003.

\section{Notes}

1 Caleb Carr, The Lessons of Terror, New York, Random House, 2002, p. 11.

2 Carr's terror-tory includes novels of crime, detection, and political prophecy in the guise of a techno-thriller: The Alienist, New York, Bantam Books, 1994; The Angel of Darkness, New York, Ballantine Books, 1997; Killing Time, New York, Warner 
Books, 2000.

3 See Nicholas Lemann, "What Terrorists Want: Is There a Better Way to Defeat Al Qaeda?" New Yorker, 77, 33, October, 29, 2001, pp. 36-41.

4 See Michael Walzer, “On 'Failed Totalitarianism',” 1984 Revisited: Totalitarianism in Our Century, Irving Howe, ed., New York, Harper and Row, 1983, pp. 103-121; J ohn S. Nelson, "Orwell's Political Myths and Ours," The Orwellian Moment, Robert L. Savage, J ames E. Combs, and Dan D. Nimmo, eds., Fayetteville, University of Arkansas Press, 1989, pp. 11-44.

5 See Søren Kierkegaard, The Concept of Dread, Walter Lowrie, trs., Princeton, NJ , Princeton University Press, 1944.

6 Hannah Arendt observed a comparable dynamic in the wake of totalitarian regimes: "The Aftermath of Nazi Rule," Commentary, 10, 4, October, 1950, pp. 342-353.

7 See Gabriel Weimann and Conrad Winn, The Theater of Terror, New York, Longman, 1994; Ferdinand Mount, The Theatre of Politics, New York, Schocken Books, 1972. Also see Robert Hariman, Political Style, Chicago, University of Chicago Press, 1995; J ohn S. Nelson, Tropes of Politics, Madison, University of Wisconsin Press, 1998.

8 See Spencer R. Weart, Nuclear Fear: A History of Images, Cambridge, MA, Harvard University Press, 1988. Also see Gunther Anders, "Reflections on the H-Bomb," Norbert Guterman, tr., Dissent, 3, 2, Spring, 1956, pp. 146-155; Ron Rosenbaum, "The Subterranean World of the Bomb," Harper's Magazine, 256, 1534, March, 1978, pp. 85-105. 